\title{
Antibacterial activity of some essential oils againts Vagococcus salmoninarum
}

\section{Vagococcus salmoninarum"a karşı bazı uçucu yağların antibakteriyel aktivitesi}

\author{
Seçil Metin $^{1^{*}}$ • Zühre Işıl Biçer² \\ 1Department of Aquaculture, Faculty of Fisheries, Isparta University of Applied Sciences, 32260 Isparta, Turkey \\ https://orcid.org/0000-0002-8029-5624 \\ 2Department of Aquaculture, Faculty of Fisheries, Isparta University of Applied Sciences, 32260 Isparta, Turkey \\ https://orcid.org/0000-0003-3669-5214 \\ Corresponding author: secil_ekici@yahoo.com \\ Received date: 08.10 .2019 \\ Accepted date: 24.12 .2019 \\ How to cite this paper: \\ Metin, S. \& Biçer, Z.I. (2020). Antibacterial activity of some essential oils againts Vagococcus salmoninarum. Ege Journal of Fisheries and Aquatic Sciences, \\ 37(2), 167-173. DOI: 10.12714/egejfas.37.2.07
}

Abstract: In this study, essential oils of thyme (Origanum vulgare), St. John's Wort (Hypericum perforatum), rosemary (Rosmarinus officinalis), ginger (Zingiber officinale), clove (Eugenia caryophyllata), peppermint (Menta piperita), lavandula (Lavandula hybrida) and black cumin (Nigella sativa) were screened for its chemical composition and in vitro antibacterial activity against Vagococcus salmoninarum. The composition of oils were analysed using GC/MS. Antibacterial effects of essential oils against $V$. salmoninarum were detected by agar diffusion and tube dilution assays. Thyme $(125 \mu \mathrm{L} \mathrm{ml-1} \mathrm{MIC})$ and clove $(500 \mu \mathrm{L} \mathrm{ml-1}$ MIC) essential oils were shown to possess strong antibacterial activity against $V$. salmoninarum. The main components of effective essential oils were carvacrol $(63.57 \%)$ and eugenol $(85.99 \%)$, respectively. As a result, these two plant species that tested against $V$. salmoninarum which is causative agent of vagococcosis can be used as an antibacterial agent. For this purpose, in vivo antibacterial activities against vagococcosis of thyme and clove essential oils should be explored in the further studies.

Keywords: Antibacterial activity, Vagococcus salmoninarum, essential oil, agar diffusion, minimal inhibitory concentration (MIC)

Öz: Bu çalışmada, kekik (Origanum vulgare), sarı kantaron (Hypericum perforatum), biberiye (Rosmarinus officinalis), zencefil (Zingiber officinale), karanfil (Eugenia caryophyllata), nane (Menta piperita), lavanta (Lavandula hybrida) ve çörek otu (Nigella sativa)'dan elde edilen uçucu yağların kimyasal bileşimleri ve Vagococcus salmoninarum'a karşı in vitro antibakteriyal etkileri incelenmiştir. Uçucu yağların kimyasal kompozisyonu Gaz Kromatografisi/Kütle Spektrometresi (GC/MS) ile analizlenmiştir. Vagococcus salmoninarum'a karşı uçucu yağların antibakteriyel etkileri agar difüzyon ve tüp dilüsyon yöntemi ile belirlenmiştir. Kekik (125 $\mu \mathrm{L} / \mathrm{ml} \mathrm{MiK})$ ve karanfil $(500 \mu \mathrm{L} / \mathrm{ml} \mathrm{MiK})$ uçucu yağlarının V. salmoninarum’a karşı güçlü antibakteriyel etkinliğe sahip olduğu görülmüştür. Etki gösteren uçucu yağlarının ana bileşenleri sırasıyla karvakrol $(\% 63,57)$ ve eugenol $(\% 85,99)$ olarak tespit edilmiştir. Sonuç olarak, vagokokkozis hastalığı etkeni V. salmoninarum'a karşı test edilen iki bitki türünün de antibakteriyel ajan olarak kullanılabileceği düşünülmektedir. Bu amaçla ilerki çalışmalarda, kekik ve karanfil uçucu yağlarının vagokokkozise karşı in vivo antibakteriyel etkinlikleri araştııımalıdır.

Anahtar kelimeler: Antibakteriyal aktivite, Vagococcus salmoninarum, uçucu yağ, agar difüzyon, minimum inhibitör konsantrasyon (MiK)

\section{INTRODUCTION}

Generically known as streptococcosis, gram-positive coccal infections are now considered as one of the main problems to aquaculture production (Ghittino et al., 2003). Vagococcosis, also called cold water streptococcosis, is pathogenic to salmonid fish at water temperatures below 12 ${ }^{\circ} \mathrm{C}$, and it is less widespread in aquaculture than other streptococcal infections (Eldar and Ghittino, 1999). Vagococcosis caused by Vagococcus salmoninarum is an important bacterial disease in the European rainbow trout industry in sub adult or adult fish, with mortality rates of 20 $50 \%$. Outbreaks in broodstocks are usually associated with post-spawning stres (Michel et al., 1997; Ghittino et al., 1999; Ruiz Zarzuela et al., 2005; Didinen et al., 2011).
V. salmoninarum has been reported in rainbow trout (Oncorhynchus mykiss) in many European countries and in Australia (Tasmania) (Schmidtke and Carson 1994; Michel et al., 1997; Ghittino et al., 1999, 2004; Ruiz-Zarzuela et al., 2005; Salogni et al., 2007) and in Atlantic salmon (Salmo salar) and brown trout (Salmo trutta) in Norway (Schmidtke and Carson 1994). The disease has been also recorded in rainbow trout broodstocks in Turkey (Didinen et al., 2011; Tanrıkul et al., 2014).

Antibiotic treatment of vagococcosis in the field has not been effective, although $V$. salmoninarum isolates are susceptible to several drugs such as ampicillin, amoxycillin, erythromycin, oxytetracycline and doxycycline tested in vitro (Michel et al., 1997; Ruiz Zarzuela et al., 2005; Didinen et al., 
2011). Treatments with antibiotics were effective only for short periods (5-7 days) and continuous application was necessary to reduce mortality.

High amounts of antibiotics are used for protection against bacterial fish diseases in the aquaculture sector in Turkey. The heavy use of antibiotics leads to the presence of its residues in fish. In addition, these antibiotic applications cause emergence of resistance in fish pathogens, including zoonotic fish bacteria. Zoonotic fish bacteria that develop resistance to antibiotics are more dangerous to humans and can cause infections that are difficult to treat (Avsever et al.,2010). Thus, it is necessary to determine and develop effective alternative protection methods against bacterial fish diseases. The use of herbal products to control of fish pathogens in aquaculture is an current practice. One of the herbal products is essential oils, which are natural components from plants that are generally recognized as safe substances. Due to their antimicrobial properties, these oils may constitute alternative prophylactic and therapeutic agents in aquaculture (Romero et al., 2012).

Phytochemicals such as phenolics, polysaccharides, proteoglycans and flavonoids may play a role in preventing or controlling infectious pathogens (Citarasu, 2010). Many essential oils and plant extracts have been shown to be effective against fish pathogens (Abutbul et al., 2005; Bansemir et al., 2006; Ekici et al., 2011; Haniffa and Kavitha, 2012; Al Laham and Al Fadel, 2014; Öntaş et al., 2016; Diler et al., 2017a,b; Metin et al., 2017). These compounds may constitute alternative prophylactic and therapeutic agents in aquaculture because of their antibacterial properties. (Turker and Birinci Yıldııı, 2015).

There are few studies on antibacterial effect of different essential oils against Vagococcus salmoninarum (Metin et al., 2017; Özay et al., 2018). The aim of this study, essential oils of thyme (Origanum vulgare), St. John's Wort (Hypericum perforatum), rosemary oil (Rosmarinus officinalis), ginger (Zingiber officinale), clove (Eugenia caryophyllata), peppermint (Menta piperita), lavandula (Lavandula hybrida) and black cumin (Nigella sativa) were screened for its chemical composition and in vitro antibacterial activity against Vagococcus salmoninarum.

\section{MATERIAL AND METHODS}

\section{Essential oils}

Essential oils of thyme (Origanum vulgare), St. John's Wort (Hypericum perforatum), rosemary oil (Rosmarinus officinalis), ginger (Zingiber officinale), clove (Eugenia caryophyllata), peppermint (Menta piperita), lavandula (Lavandula hybrida) and black cumin (Nigella sativa) were purchased from Botalife.

\section{Gas chromatography-mass spectroscopy analyses of essential oils}

The gas chromatographic analysis of essential oils was performed with a Hewlett-Packard 6890 series gas chromatograph (Perkin Elmer (PE) Auto System XL, Alameda, CA, USA), fitted with a flame ionization detector (FID). Relative percentage amounts were calculated from chromatograms by the Turbo Crom. Navigator computer program.

\section{In vitro antibacterial assays}

Antibacterial effects of essential oils against $V$. salmoninarum were detected by agar diffusion and tube dilution assays.

\section{Agar difusion assay}

V. salmoninarum was grown in TSB for $24 \mathrm{~h}$ at $25^{\circ} \mathrm{C}$, and $100 \mu \mathrm{L}$ of bacteria culture was mixed into $100 \mathrm{~mL}$ of melted TSA. After solidifying and drying for 15-20 minute, wells were punched (diameter $=3 \mathrm{~mm}$ ) and $25 \mu \mathrm{L}$ of different concentrations prepared with $96 \%$ ethanol (the test concentrations: $1000,500,250,125,62.5,31.25,15.62$ and $7.8 \mu \mathrm{ml}^{-1}$ ) added to wells in triplicates. Controls were prepared using $96 \%$ ethanol. Plates were incubated at $25^{\circ} \mathrm{C}$ for $24 \mathrm{~h}$ and observed for clearing zones around the wells. The concentrations of essential oils causing clearing zones were determined (NCCLS, 2001).

\section{Tube dilution assay}

The mininum inhibition concentration (MIC) of essential oils were determined by using the broth dilution method. The essential oil was dissolved in $96 \%$ ethanol and serially diluted $\left(1000-0.01 \mu \mathrm{mL}^{-1}\right)$. The ethanol was used as control. V. salmoninarum was cultured in TSA for $24 \mathrm{~h}$ at $25^{\circ} \mathrm{C}$ then diluted to a concentration of McFarland No.0.5. Then, $V$. salmoninarum was introduced into each tube under sterile conditions and incubated for $48 \mathrm{~h}$ at $25^{\circ} \mathrm{C}$. After incubation, MIC values were recorded as the lowest concentration of the oils that completely inhibited bacterial growth (Park et al., 2016).

\section{Statistical analysis}

One-way analysis of variance and Duncan's multiple range tests were run to evaluate the differences using the SPSS software (Version 15, SPSS Inc., Chicago, IL, USA). The means and standard errors were calculated for each treatment. The accepted level of significance was 0.05 .

\section{RESULTS}

\section{In vitro antibacterial assays}

In vitro antibacterial activities of the essential oils against $V$. salmoninarum were determineted by the agar diffusion and tube dilution methods. The antibacterial activities of different essential oils against $V$. salmoninarum were summarized in Table 1 and 2. The antibacterial activity of thyme (Origanum vulgare), St. John's Wort (Hypericum perforatum), rosemary oil 
(Rosmarinus officinalis), ginger (Zingiber officinale) and black cumin (Nigella sativa) were studied for the first time. A broad variation in antimicrobial properties of the tested essential oils was observed in the study.

The essential oils of thyme and clove showed strong antimicrobial activity at different concentrations against $V$. salmoninarum, whereas other essential oils did not show any antibacterial activity. The maximum inhibition zones and MIC values of the essential oils of thyme and clove againts $V$. salmoninarum were in the range of 20.33-18 $\mathrm{mm}$ and $125-1000$ $\mu \mathrm{l} \mathrm{ml}-1,17.83-18.66 \mathrm{~mm}$ and $500-1000 \mu \mathrm{ml}^{-1}$, respectively (Table 1, 2).

Table 1. Antibacterial activity of essential oils against $V$. salmoninarum by the agar diffusion assay (The diameter of the zone of inhibition, $\mathrm{mm}$ )

\begin{tabular}{|c|c|c|c|c|c|c|}
\hline $\begin{array}{l}\text { Concentration } \\
\mu \mathrm{l} \mathrm{ml}^{-1}\end{array}$ & Thyme & Clove & Ginger & Peppermint & Rosemary & Lavandula \\
\hline 1000 & $18 \pm 2,0^{a b}$ & $18.66 \pm 0,57^{a}$ & $5.66 \pm 0,57$ & $6.66 \pm 0,57 \mathrm{ab}$ & - & - \\
\hline 500 & $20 \pm 1,0^{a}$ & $17.83 \pm 0,76^{a}$ & $5.66 \pm 0,57$ & $6 \pm 1,0^{b c}$ & - & - \\
\hline 250 & $18 \pm 1,0 \mathrm{ab}$ & $11.66 \pm 1,52^{b}$ & $5.66 \pm 0,57$ & $7.83 \pm 0,28^{a}$ & - & - \\
\hline 125 & $20.33 \pm 1,52^{a}$ & $11.83 \pm 0,28 b$ & $6 \pm 00$ & $6.83 \pm 0,76 \mathrm{ab}$ & - & - \\
\hline 62.5 & $17 \pm 1,0^{b}$ & $11 \pm 0^{b}$ & - & $6.5 \pm 0,5^{b c}$ & - & - \\
\hline 31.25 & $12.66 \pm 1,52^{c}$ & $8.66 \pm 0,57^{c}$ & - & $5.33 \pm 0,57^{c}$ & - & - \\
\hline 15.62 & $10.66 \pm 1,52^{c}$ & $7.16 \pm 0,28^{d}$ & - & - & - & - \\
\hline 7.8 & $8.16 \pm 0,28 d$ & $5.83 \pm 0,76 \mathrm{e}$ & - & - & - & - \\
\hline
\end{tabular}

Table 2. Minimum inhibitory concentration of essential oils against $V$. salmoninarum $\left(\mu \mathrm{ml}^{-1}\right)$

\begin{tabular}{ccccccc}
\hline $\begin{array}{c}\text { Concentration } \\
\mu l \mathrm{ml}^{-1}\end{array}$ & Thyme & Clove & Ginger & Peppermint & Rosemary & Lavandula \\
\hline 1000 & - & - & - & - & + & + \\
500 & - & - & + & + & + & + \\
250 & - & + & + & + & + & + \\
125 & - & + & + & + & + & + \\
62.5 & + & + & + & + & + & + \\
31.25 & + & + & + & + & + & + \\
15.62 & + & + & + & + & + & + \\
7.8 & + & + & + & + & + & + \\
3.9 & + & + & + & + & + & + \\
1.95 & + & + & + & + & + & + \\
0.97 & + & + & + & + & + & + \\
0.48 & + & + & + & + & + & + \\
0.24 & + & + & + & + & + & + \\
0.12 & + & + & + & + & + & + \\
0.06 & + & + & + & + & + & + \\
0.03 & + & + & + & + & + & + \\
0.01 & + & + & + & + & +
\end{tabular}

\section{GC-MS Analysis}

The results of the chemical analysis of effective essential oils are presented in Table 3. Twenty one components were identified in thyme oil and the main components were carvacrol
(63.57\%) and cymol (16.09\%). In clove oil, only five components were detected and the main components were eugenol (85.99\%) and caryophyllene (10.89\%). 
Metin and Biçer, Ege Journal of Fisheries and Aquatic Sciences, 37(2), 167-173 (2020)

Table 3. Chemical composition of thyme and clove essential oils

\begin{tabular}{|c|c|c|c|}
\hline Essential oil & Component & Composition (\%) & Retention Time (RT) \\
\hline \multirow{22}{*}{ Rosmarinus officinalis } & Thujene<alpha-> & 0.11 & 6.298 \\
\hline & Alpha pinene & 12.85 & 6.566 \\
\hline & Camphene & 5.01 & 7.121 \\
\hline & Pinene<beta-> & 8.48 & 8.160 \\
\hline & Beta.-Myrcene & 1.31 & 8.585 \\
\hline & 1-Phellandrene & 0.10 & 9.321 \\
\hline & .DELTA.3-Carene & 0.06 & 9.449 \\
\hline & Terpinene<alpha-> & 0.04 & 9.808 \\
\hline & Cymol & 3.04 & 10.154 \\
\hline & Limonene & 2.01 & 10.425 \\
\hline & 1,8-Cineole & 47.31 & 10.593 \\
\hline & Cis-Ocimene & 0.05 & 10.712 \\
\hline & Gamma.-Terpinen & 0.87 & 11.815 \\
\hline & Alpha.-Terpinolen & 0.07 & 13.253 \\
\hline & Linalyl acetate & 0.14 & 14.044 \\
\hline & Camphor & 12.04 & 16.706 \\
\hline & Isoborneol & 0.06 & 17.680 \\
\hline & Borneol & 2.62 & 18.229 \\
\hline & Trans-4-Thujanol & 0.20 & 18.789 \\
\hline & .BETA. FENCHYL ALCOHOL & 2.17 & 19.724 \\
\hline & Bornyl acetate & 1.00 & 25.500 \\
\hline & Caryophyllene & 0.47 & 34.107 \\
\hline \multirow{12}{*}{ Menta piperita } & Isopulegol \& p-Menthen-3-ol & 1.98 & 16.820 \\
\hline & Menthone & 24.20 & 17.329 \\
\hline & Isomenthone (CAS) p-Menthan-3-one & 9.28 & 17.828 \\
\hline & Neoisomenthol & 11.35 & 18.199 \\
\hline & Isopulegone & 0.77 & 18.473 \\
\hline & Menthol & 44.76 & 18.830 \\
\hline & ALPHA. TERPINEOL & 0.81 & 19.735 \\
\hline & Pulegone & 3.91 & 22.428 \\
\hline & Piperitone & 0.80 & 23.409 \\
\hline & Neomenthol acetate & 2.03 & 25.961 \\
\hline & Beta.-Bourbonene & 0.05 & 31.855 \\
\hline & Trans- Caryophyllene & 0.05 & 34.109 \\
\hline \multirow{21}{*}{ Origanum vulgare } & Thujene<alpha-> & 1.67 & 6.290 \\
\hline & .ALPHA.-PINENE, (-)- & 1.88 & 6.549 \\
\hline & 2,4(10)-thujadien & 0.14 & 6.869 \\
\hline & Camphene & 1.67 & 7.111 \\
\hline & 2-.BETA.-PINENE & 0.75 & 8.147 \\
\hline & .beta.-Myrcene & 1.30 & 8.576 \\
\hline & 1-Phellandrene & 0.17 & 9.310 \\
\hline & .DELTA.3-Carene & 0.09 & 9.435 \\
\hline & .ALPHA. TERPINENE & 1.28 & 9.792 \\
\hline & Cymol & 16.09 & 10.148 \\
\hline & Limonene & 0.56 & 10.378 \\
\hline & EUCALYPTOL (1,8-CINEOLE) & 0.87 & 10.508 \\
\hline & .gamma.-Terpinene & 2.65 & 11.808 \\
\hline & Trans-4-Thujanol & 1.36 & 12.394 \\
\hline & .ALPHA.-TERPINOLENE & 0.21 & 13.243 \\
\hline & Borneol & 2.56 & 18.209 \\
\hline & Trans-Sabinene hydrate & 0.84 & 18.780 \\
\hline & .BETA. FENCHYL ALCOHOL & 0.26 & 19.722 \\
\hline & Thymol & 0.24 & 26.050 \\
\hline & Carvacrol & 63.57 & 26.715 \\
\hline & Caryophyllene & 1.86 & 34.113 \\
\hline
\end{tabular}




\begin{tabular}{|c|c|c|c|}
\hline \multirow{26}{*}{ Zingiber officinale } & .ALPHA.-PINENE, (-)- & 2.07 & 6.538 \\
\hline & Camphene & 7.07 & 7.108 \\
\hline & BETA.-PINENE & 0.22 & 8.133 \\
\hline & 6-Methyl-5-hepten-2-one & 0.51 & 8.325 \\
\hline & .beta.-Myrcene & 0.67 & 8.573 \\
\hline & 1-Phellandrene & 5.05 & 10.434 \\
\hline & EUCALYPTOL (1,8-CINEOLE) & 3.05 & 10.496 \\
\hline & Linaly formate & 0.10 & 14.031 \\
\hline & BORNEOL L & 0.94 & 18.204 \\
\hline & .BETA. FENCHYL ALCOHOL & 0.39 & 19.697 \\
\hline & Copaene <alpha-> & 0.47 & 31.390 \\
\hline & Geranyl butyrate & 0.22 & 31.797 \\
\hline & .BETA. ELEMENE & 0.74 & 32.344 \\
\hline & Sesquithujene $<7$-epi-> & 0.21 & 33.308 \\
\hline & GERMACRENE-D & 1.02 & 37.998 \\
\hline & Curcumene & 11.65 & 38.229 \\
\hline & Alloaromadendrene & 1.19 & 38.933 \\
\hline & Zingiberene & 37.18 & 39.215 \\
\hline & Farnesene $<(E, E)-$, alpha- $>$ & 4.07 & 39.851 \\
\hline & Bisabolene & 7.95 & 39.954 \\
\hline & Cedrene & 13.50 & 40.898 \\
\hline & Patchoulene <alpha-> & 0.34 & 41.039 \\
\hline & & 0.29 & 42.204 \\
\hline & Germacrene B & 0.49 & 42.687 \\
\hline & d-Nerolidol & 0.27 & 43.160 \\
\hline & .alpha.-Cedrol & 0.31 & 46.220 \\
\hline \multirow{5}{*}{ Eugenia caryophyllata } & Chavicol\$ $\$ p-A l l y l p h e n o l$ & 0.12 & 23.455 \\
\hline & Eugenol & 85.99 & 30.381 \\
\hline & Caryophyllene & 10.89 & 34.199 \\
\hline & Alpha.-Humulene & 2.45 & 36.388 \\
\hline & (-)-Caryophyllene oxide & 0.54 & 44.036 \\
\hline \multirow{22}{*}{ Lavandula hybrida } & Alpha-Pinene & 0.26 & 6.551 \\
\hline & Camphene & 0.26 & 7.116 \\
\hline & Beta-Pinene & 0.21 & 8.149 \\
\hline & 3-Octanone (CAS) EAK & 0.93 & 8.373 \\
\hline & Beta-Myrceneethanoate & 0.84 & 8.583 \\
\hline & Ethanoate <hexyl-> & 1.04 & 9.536 \\
\hline & Limonene & 0.85 & 10.379 \\
\hline & 1,8-Cineole & 4.95 & 10.505 \\
\hline & Cis-Ocimene & 0.95 & 10.699 \\
\hline & Trans-.beta.-Ocimene & 2.30 & 11.224 \\
\hline & ALPHA.-TERPINOLEN & 0.24 & 13.257 \\
\hline & Linalool & 42.31 & 14.164 \\
\hline & Camphor & 5.16 & 16.657 \\
\hline & Propanoic acid, 2-methyl-, hexyl ester & 0.24 & 16.901 \\
\hline & BORNEOL L & 1.99 & 18.220 \\
\hline & Linalool & 2.40 & 19.698 \\
\hline & Linalyl acetate & 32.16 & 23.515 \\
\hline & Lavandulyl acetate & 1.22 & 25.671 \\
\hline & Neryl acetate & 0.45 & 31.800 \\
\hline & Caryophyllene & 0.87 & 34.114 \\
\hline & Farnesene $<(E)$-, beta- $>$ & 0.28 & 36.573 \\
\hline & GERMACRENE-D & 0.08 & 37.991 \\
\hline
\end{tabular}




\section{DISCUSSION}

Essential oils isolated from different aromatic plants are known to have a wide spectrum of antimicrobial activity (Hammer et al., 1999; Baydar et al., 2004). This activity is strongly correlated with the chemical structure of the most abundant essential oil component. The chemical composition of essential oils depends on climatic, seasonal and geographic conditions, harvest period. The chemical components of thyme and clove essential oils have been studied in literatures. The phenolic monoterpens (carvacrol and thymol) are the most abundant constituent of the essential of Origanum species. The composition of 0 . vulgare essential oil has been characterized by several authors, with carvacrol as the major components (Goliaris et al., 2003; Viuda-Martos et al., 2007; Souza et al., 2008; De Martino et al., 2009; Derwich et al., 2010; Bejaoui et al., 2013; Stojkovic et al., 2013; Diler et al., 2017b). Other components have also been reported as important essential oil components, such as pcymene, $\mathrm{y}$-terpinene, caryophyllene, spathulenol, thymoquinene and germacrene (Milos et al., 2000; Radusiene et al., 2005; Cleff et al., 2010; Teixeira et al., 2013). In another study, the main constituents of $O$. vulgare essential oils have been reported as thymol (13.7-85.9\%) and carvacrol $(1.5-63.0 \%)$ (Raina and Negi, 2014). In the present study, carvacrol $(63.57 \%)$ and cymol $(16.09 \%)$ were detected of main components of 0 . vulgare essential oil. However, thymol content $(0.24 \%)$ found to be quite low. The major component of clove oil is usually considered to be eugenol, with $\beta$ caryophyllene and lesser amounts of other components such as benzyl alcohol, but the proportions vary widely (Chaieb et al., 2007; Guan et al., 2007; Xu et al., 2016). For example,

\section{REFERENCES}

Abutbul, S., Golan-Goldhirsh, A., Barazani, O., Ofir, R. \& Zilberg, D. (2005). Screening of desert plants for use against bacterial pathogens in fish. Israeli Journal of Aquaculture- Bamidgeh, 57(2), 71-80.

Al Laham, S. A. \& Al Fadel, F. M. (2014). Antibacterial activity of various plants extracts against antibiotic-resistant Aeromonas hydrophila. Jundishapur Journal of Microbiology, 7(7),1-7. DOI: 10.5812/jjm.11370

Avsever, M. L., Türk, N. \& Tunalıgil, S. (2010). The increase of antibiotic resistance in aquaculture and its effects on human health. Bornova Veteriner Kontrol ve Araștirma Enstitüsü Dergisi, 32(46), 19-23.

Bansemir, A., Blume, M., Schröder, S. \& Lindequist, U. (2006). Screening of cultivated seaweeds for antibacterial activity against fish pathogenic bacteria. Aquaculture, 252(1), 79-84. DOI: 10.1016/j.aquaculture.2005.11.051

Baydar, H., Sağdiç, O., Özkan, G. \& Karadoğan, T. (2004). Antibacterial activity and composition of essential oils from Origanum, Thymbra and Satureja species with commercial importance in Turkey. Food Control, 15(3), 169-172. DOI: 10.1016/S0956-7135(03)00028-8

Bejaoui, A., Chaabane, H., Jemli, M., Boulila, A., \& Boussaid, M. (2013). Essential oil composition and antibacterial activity of Origanum vulgare subsp. glandulosum Desf. at different phenological stages. Journal of Medicinal Food, 16(12), 1115-1120. DOI: 10.1089/jmf.2013.0079

Chaieb, K., Hajlaoui, H., Zmantar, T., Kahla-Nakbi, A. B., Rouabhia, M., Mahdouani, K. \& Bakhrouf, A. (2007). The chemical composition and biological activity of clove essential oil, Eugenia caryophyllata (Syzigium aromaticum L. Myrtaceae): a short review. Phytotherapy Research, 21(6), 501-506. DOI: 10.1002/ptr.2124
Prashar et al. (2006) found the content of eugenol to be $78 \%$, with $13 \% \beta$-caryophyllene, whereas Chaieb et al. (2007) found that eugenol was $88.58 \%$, with $\beta$-caryophyllene at $1.39 \%$. In this study, similarly eugenol $(85.99 \%)$ and caryophyllene $(10.89 \%)$ were determined as main components of clove oil.

In this study, antimicrobial effects of thyme, black cumin, ginger, rosemary oil and St. John's Wort against Vagococcus salmoninarum were investigated for the first time. The essential oils of thyme and clove showed strong antimicrobial activity at different concentrations against V. salmoninarum. However, St. John's Wort, rosemary oil, ginger, peppermint, lavandula and black cumin essential oils did not show any antibacterial activity. In another study, cyclamen L. tuber extracts had been found to have moderate antibacterial activity againts $V$. salmoninarum (Özay et al., 2018). Metin et al. (2017) noted that clove essential oil was showed a strong antimicrobial activity

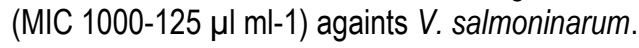

In conclusion, thyme and clove essential oils displayed stronger inhibition zones against $V$. salmoninarum. This is a critical step in determining whether such essential oils are capable of reducing mortality caused by these pathogens. However, thyme and clove oil is needed further study to explore its therapeutic effects against vagococcosis

\section{ACKNOWLEDGMENT}

This study was financially supported by Suleyman Demirel University, Scientific Research Project Grant (SDU BAP 4031YL1-14). This study is summarized from master thesis of Zühre Işıl Biçer.

Citarasu, T. (2010). Herbal biomedicines: a new opportunity for aquaculture industry. Aquaculture International, 18(3), 403-414. DOI: $10.1007 / s 10499-009-9253-7$

Cleff, M.B., Meinerz, A.R., Xavier, M., Schuch, L.F., Meireles, M.C.A., Rodrigues, M.R.A. \& Mello, J.R.B.D. (2010). In vitro activity of Origanum vulgare essential oil against Candida species. Brazilian Journal of Microbiology, 41(1), 116-123. DOI: $10.1590 /$ S1517-83822010000100018

De Martino, L., De Feo, V., Formisano, C., Mignola, E. \& Senatore, F. (2009). Chemical composition and antimicrobial activity of the essential oils from three chemotypes of Origanum vulgare L. ssp. hirtum (Link) letswaart growing wild in Campania (Southern Italy). Molecules, 14(8), 2735-2746. DOI: $10.3390 /$ molecules14082735

Derwich, E., Benziane, Z., Manar, A., Boukir, A., \& Taouil, R. (2010). Phytochemical analysis and in vitro antibacterial activity of the essential oil of Origanum vulgare from Morocco. American-Eurasian Journal of Scientific Research, 5(2), 120-129.

Didinen, B. I., Kubilay, A., Diler, O., Ekici, S., Onuk, E. E. \& Findik, A. (2011). First isolation of Vagococcus salmoninarum from cultured rainbow trout (Oncorhynchus mykiss, Walbaum) broodstocks in Turkey. Bulletin of the European Association of Fish Pathologists,31(6), 235-243.

Diler, O., Gormez, O., Diler, I. \& Metin, S. (2017a). Effect of oregano (Origanum onites L.) essential oil on growth, lysozyme and antioxidant activity and resistance against Lactococcus garvieae in rainbow trout, Oncorhynchus mykiss (Walbaum). Aquaculture Nutrition, 23(4), 844-851. DOI: 10.1111/anu.12451 
Diler, Ö., Görmez, Ö., Metin, S., IIhan, I. \& Diler, İ. (2017b). Origanum vulgare L. uçucu yağının gökkuşağı alabalıkları (Oncorhyncus mykiss)'nda büyüme, lizozim ve antioksidan aktivite ve Vibrio anguillarum'a karşı direnç üzerine etkisi. Süleyman Demirel Üniversitesi Eğirdir Su Ürünleri Fakültesi Dergisi, 13(1), 42-57. DOI: 10.22392/egirdir.252029

Ekici, S., Diler, Ö., Didinen, B.I. \& Kubilay, A. (2011). Antibacterial activity of essential oils from medicinal plants against bacterial fish pathogens. Kafkas Üniversitesi Veteriner Fakültesi Dergisi, 17(Supplement A), 47-54.

Eldar, A. A. \& Ghittino, C. (1999). Lactococcus garvieae and Streptococcus iniae infections in rainbow trout Oncorhynchus mykiss: similar, but different diseases. Diseases of aquatic organisms,36(3), 227-231. DOI: 10.3354/da0036227

Ghittino, C., Accornero, P., Prearo, M., Rogato, F., Zlotkin, A. \& Eldar, A. (1999). Coldwater streptococcoses in salmonids, with particular reference to Vagococcus salmoninarum infection. Proceedings of Workshop in Fish Streptococcoses, IZS - State Veterinary Institute, Turin, Italy, 3.

Ghittino, C., Agnetti, F., Panzieri, C., Cabra, S., Colussi, S. \& Prearo, M. (2004). L'infezione da Vagococcus salmoninarum della trota iridea in Italia. Ittiopatologia, 1, 25-33.

Ghittino, C., Latini, M., Agnetti, F., Panzieri, C., Lauro, L., Ciappelloni, R. \& Petracca, G. (2003). Emerging pathologies in aquaculture: effects on production and food safety. Veterinary Research Communications, 27(1), 471-479. DOI: 10.1023/B:VERC.0000014204.37722.b6

Goliaris, A. H., Chatzopoulou, P. S. \& Katsiotis, S. T. (2003). Production of new Greek oregano clones and analysis of their essential oils. Journal of Herbs, Spices \& Medicinal Plants, 10(1), 29-35. DOI: 10.1300/J044v10n01_04

Guan, W., Li, S., Hou, C., Yan, R. \& Ma, J. (2007). Determination and correlation of solubilities of clove oil components in supercritical carbon dioxide. Journal of Chemical Industry and Engineering, 58, 1077-1081.

Hammer, K.A., Carson, C.F. \& Riley, T.V. (1999). Antimicrobial activity of essential oils and other plant extracts. The Journal of Applied Microbiology, 86(6): 985-990. DOI: 10.1046/j.1365-2672.1999.00780.x

Haniffa, M.A. \& Kavitha, K. (2012). Antibacterial activity of medicinal herbs against the fish pathogen Aeromonas hydrophila. Journal of Agricultural Technology, 8(1), 205-211.

Kara, N. \& Baydar, H. (2013). Determination of lavender and lavandin cultivars (Lavandula sp.) containing high quality essential oil in Isparta, Turkey. Turkish Journal of Field Crops, 18(1), 58-65.

Kumar, P., Mishra, S., Malik, A. \& Satya, S. (2011). Insecticidal properties of Mentha species: a review. Industrial Crops and Products, 34(1), 802-817. DOI: 10.1016/j.indcrop.2011.02.019

Metin, S., Didinen, B.I., Mercimek, E.B. \& Ersoy, A.T. (2017). Antibacterial Activity of Some Essential Plant Oils Againts Some Bacterial Fish Pathogens. Aquaculture Studies, 17(1), 059-069.

DOI: 10.17693/yunusae.v17i26557.280204Michel, C., Nougayrede, P., Eldar, A., Sochon, E., \& De Kinkelin, P. (1997). Vagococcus salmoninarum, a bacterium of pathological significance in rainbow trout Oncorhynchus mykiss farming. Diseases of Aquatic Organisms, 30, 199208. DOI: $10.3354 /$ dao030199

Mılos, M., Mastelic, J. \& Jerkovic, I. (2000). Chemical composition and antioxidant effect of glycosidically bound volatile compounds from Oregano (Origanum vulgare L. ssp. hirtum). Food Chemistry, 71, 79-83. DOI: 10.1016/S0308-8146(00)00144-8

NCCLS, (2001). Testing; Eleventh Information Supplement. NCCLS document M100-S11 NCCLS, Pennsylvania, USA.

Noori, S., Zeynali, F. \& Alması, H. (2018). Antimicrobial and antioxidant efficiency of nanoemulsion-based edible coating containing ginger (Zingiber officinale) essential oil and its effect on safety and quality attributes of chicken breast fillets. Food Control, 84, 312-320. DOI: 10.1016/j.foodcont.2017.08.015

Öntaş, C., Baba, E. \& Kaplaner, E. (2016). Antibacterial activity of Citrus limon peel essential oil and Argania spinosa oil against fish pathogenic bacteria. Journal of the Faculty of Veterinary Medicine, Kafkas University, 22, 741749. DOI: 10.9775/kvfd.2016.15311
Özay, C., Ulukoy, G., Mammadov, R. \& Sayın, Z. (2018). Radical scavenging activity and antibacterial effect of three cyclamen I. tuber extracts on some fish pathogens. SDÜ Journal of Natural and Applied Sciences, 22(2), 562568. DOI: 10.19113/sdufbed.65047

Park, J.W., Wendt, M. \& Heo, G.J. (2016). Antimicrobial activity of essential oil of Eucalyptus globulus against fish pathogenic bacteria. Laboratory Animal Research, 32(2), 87-90. DOI: 10.5625/lar.2016.32.2.87

Prashar, A., Locke, I.C. \& Evans, C.S. (2006). Cytotoxicity of clove (Syzygium aromaticum) oil and its major components to human skin cells. Cell Proliferation, 39, 241-248. DOI: 10.1111/j.1365-2184.2006.00384.x

Radusıene, J., Judpıntıenë, A., Peèıulytë, D. \& Janulıs, V. (2005). Chemical composition of essential oil and antimicrobial activity of Origanum vulgare. Biologija, 4, 53-58.

Raına, A.P. \& Negi, K.S. (2014). Chemical diversity among different accessions of Origanum vulgare L. ssp. vulgare collected from Central Himalayan region of Uttarakhand, India. Journal of Essential Oil Research, 26(6), 420-426. DOI: 10.1080/10412905.2014.948969

Ribeiro-Santos, R., Carvalho-Costa, D., Cavaleiro, C., Costa, H.S., Albuquerque, T.G., Castilho, M.C., Ramos, F., Melo, M.R. \& SanchesSilva, A. (2015). A novel insight on an ancient aromatic plant: The rosemary (Rosmarinus officinalis L.). Trends in Food Science \& Technology, 45(2), 355-368. DOI: 10.1016/.t.tifs.2015.07.015

Romero, J., Feijoó, C. G. \& Navarrete, P. (2012). Antibiotics in aquacultureuse, abuse and alternatives. Health and Environment in Aquaculture, 159198. DOI: $10.5772 / 28157$

Ruız-Zarzuela, I., De Blas, I., Girones, O., Ghittino, C. \& Muzquiz, JL. (2005). Isolation of Vagococcus salmoninarum in rainbow trout Oncorhynchus mykiss (Walbaum), broodstocks: characterisation of the pathogen. Veterinary Research Communications, 29, 553-562. DOI: 10.1007/s11259-005-2493-8

Salogni, C., Perantoni, P., Pitozzi, A., Loris, G. \& Alboralı, G.L. (2007). Vagococcus salmoninarum: descrizione di un focolaio di malattia in riproduttori di trota iridea (Oncorhynchus mykiss). Ittiopatologia, 4, 59-66.

Schmidtke, L.N. \& Carson, J. (1994). Characteristics of Vagococcus salmoninarum isolated from diseased salmonid fish. Journal of Applied Bacteriology, 77, 229-236. DOI: 10.1111/j.1365-2672.1994.tb03068.x

Souza, E.L., Barros, J.C., Oliveira, C.E.V. \& Conceicao, M.L. (2008). Influence of Origanum vulgare L. essential oil on enterotoxin production, membrane permeability and surface characteristics of Staphylococcus aureus. The International Journal of Food Microbiology, 137(2-3), 308-311. DOI: 10.1016/j.ijfoodmicro.2009.11.025

Stojkovic, D., Glamočlija, J., Ćirić, A., Nikolić, M., Ristić, M., Šiljegović, J., \& Sokovic, M. (2013). Investigation on antibacterial synergism of Origanum vulgare and Thymus vulgaris essential oils. Archives of Biological Sciences, 65(2), 639-643.

Tanrıkul, T., Avsever, M.L., Onuk, E.E. \& Didinen, B.I. (2014). Vagococcus salmoninarum, a causative agent of disease in rainbow trout (Oncorhynchus mykiss, Walbaum) broodstocks in the aegean region of Turkey. Etlik Veterinary Microbiology Journal, 25,11-16.

Teixeira, B., Marques, A., Ramos, C., Serrano, C., Matos, O., Neng, N.R., Nogueira, J.M.F., Saraiva, J.A. \& Nunes, M.L. (2013). Chemical composition and bioactivity of different oregano (Origanum vulgare) extracts and essential oil. The Journal of the Science of Food and Agriculture, 93, 2707-2714. DOI: 10.1002/jsfa.6089

Turker, H. \& Yıldırım, A.B. (2015). Screening for antibacterial activity of some Turkish plants against fish pathogens: a possible alternative in the treatment of bacterial infections. Biotechnology \& Biotechnological Equipment, 29(2), 281-288. DOI: 10.1080/13102818.2015.1006445

Viuda-Martos, M., Ruiz-Navajas, Y., Fernandez-Lopez, J. \& Perez-Alverez, J.A. (2007). Chemical composition of the essential oils obtained from some spices widely used in mediterranean region. Acta Chimica Slovenica, 54, 921-926.

Xu, J.G., Lıu, T., Hu, Q.P. \& Cao, X.M. (2016). Chemical composition, antibacterial properties and mechanism of action of essential oil from clove buds against Staphylococcus aureus. Molecules, 21(9), 1194. DOI: 10.3390/molecules21091194 